\title{
Economic Effect of Organic and Inorganic Fertilizers on the Yield of Maize in Oyo State, Nigeria
}

\author{
Adelomo Bosede Sekumade \\ Department of Agricultural Economics and Extension Services, Ekiti State University, Ado Ekiti, Nigeria
}

Email address:

adelomo.sekumade@eksu.edu.ng

\section{To cite this article:}

Adelomo Bosede Sekumade. Economic Effect of Organic and Inorganic Fertilizers on the Yield of Maize in Oyo State, Nigeria. International Journal of Agricultural Economics. Vol. 2, No. 3, 2017, pp. 63-68. doi: 10.11648/j.ijae.20170203.13

Received: March 10,2017; Accepted: March 24, 2017; Published: April 14, 2017

\begin{abstract}
The study analyzed the economic effect of organic and inorganic fertilizers on the yield of maize in Oyo State, Nigeria. The study used purposive sampling techniques and data were collected from one-hundred and twenty maize farmers through a well- structured questionnaire. The collected data were analyzed using descriptive statistics and inferential statistics like multinomial logit regression and budgetary technique analysis. Results from descriptive analysis showed that $76.70 \%$ of the maize farmers were male while $78.90 \%$ were above 50 years old. The results further revealed that $66.70 \%$ of the farmers were married while $40.00 \%$ had secondary education and above. Majority $(83.4 \%)$ of the respondents had about at least 5 members that constitute the household in the study area. It was revealed from the results that $90 \%$ of the farmers interviewed chose farming as their primary occupation. Also, $54.2 \%$ of the farmers had at least 4 hectares of farm size while $53.3 \%$ of them had at most 21 years of farming experience. The determinants of choice for organic fertilizers were educational level, access to loan, access to extension contact, primary occupation and farm size, the determinants of choice for inorganic fertilizers were found to be educational level, primary occupation, farming experience, membership of cooperative and farm size. From the costs and returns breakdown of organic fertilizers users in the study area, the cost ratio showed that an inorganic farmer user that invested $\$ 1$ realized $\$ 1.59$ as revenue or gained $¥ 0.59 \mathrm{k}$ on each Naira expended, while an organic farmer user that invested $¥ 1$ realized 1.67 as revenue or gained $\$ 0.67 \mathrm{k}$ on each Naira expended. If inorganic fertilizer will be difficult to access by farmers, then government must encourage farmers to use the organic type due to its cheapness and availability. It is therefore recommended that government should embark on moves that will encourage youths' involvement in maize production and prevent the fertilizer subsidy program from going into extinction.
\end{abstract}

Keywords: Maize Farmers, Organic Fertilizers, Inorganic Fertilizers, Multinomial Logit, Budgetary Technique Analysis

\section{Introduction}

Maize is the most important cereal crop in sub-Saharan Africa (SSA) and an important staple food for more than 1.2 billion people in SSA and Latin America [1]. Among the priority crops under the agricultural program flagship of the Nigerian government in 2012, maize crop takes the lead [2]. In order to ensure food security and improve maize farmers' economic situation, government initiative have been launched to increase yields with the help of fertilizer [3]. This initiative has however enabled farmers to receive the support of the Federal Ministry of Agriculture in terms of access to subsidized fertilizer. The economic importance of maize cannot be over-emphasized, as every of its part has economic value [1].

Organic fertilizers are fertilizers derived from animal matter, human excreta or vegetable matter (e.g. compost, manure), while inorganic fertilizer, also referred to as synthetic fertilizer, is manufactured artificially and contains minerals or synthetic chemicals. Fertilizer use, especially the inorganic one is generally low in Africa as most farmers are satisfied with the fertility state of their soil. [4] gave some potential reasons for low fertility use rates as: high fertilizer cost, lack of irrigation systems, prevalence of traditional crop varieties that are less responsive to fertilizer and low incentives to invest in land-saving technologies. In Nigeria, the explanatory factors adduced to low fertilizer use include farmers' awareness of fertilizer's benefits, credit constraints and political instability [5].

Soil fertility in African soils has decreased over time, with an annual net nutrient depletion rate exceeding $30 \mathrm{~kg} \mathrm{~N}$ ha-1 [3] as a result of continuous cropping with inadequate nutrient 
replenishment [6]. In most of smallholder farms, these deficiencies can be replenished through the use of mineral fertilizers and organic fertilizer like cattle manure. However, majority of smallholder farmers cannot afford mineral fertilizers, and those using fertilizer hardly use the recommended rates [7]. Moreover, the little fertilizer available when added to the soil is often utilized with poor efficiency [8] due to environmental or soil-related factors and management factors (e.g. poor timing or placement of fertilizer). On the other hand, the use of locally available manure is also limited by its low quality and quantity [9, $10 \& 11]$.

In addition to using more affordable inputs, locally available soil organic inputs could be used to improve declining soil fertility in Sub-Saharan Africa through enhancing soil carbon and soil biological properties. For instance, [12] reported a $92 \%$ increase in maize grain yields after applying manure compared to the control. [13] Also recognized the beneficial effects when mineral fertilizer was used together with manures in rehabilitating degraded soils.

Adoption of any new technology depends on farmer's perceptions of financial benefits, particularly when additional labour is required in the establishment and management of these technologies. Farmers are likely to adopt soil fertility improving technologies if they are assured of returns to investments [12]; therefore, it is paramount to account for economic returns of organic and inorganic fertilizer usage in the production of maize. This study however analyzed the economic effect of organic and inorganic fertilizers among small-holders maize farmers in Oyo state, Nigeria.

\section{Methodology}

\subsection{Study Area}

The study was conducted in Oyo state, Nigeria. Oyo state was created on the $3^{\text {rd }}$ of February, 1976 with the capital located in Ibadan. Oyo state has its coordinate located on $8^{\circ}$ $00^{\prime} \mathrm{N} 4^{\circ} 00^{\prime} \mathrm{E}$. Oyo state was carved out of former western state and originally included Osun state which split off in 1991. According to National Population Commission (2006), Oyo state has a population of 5,591,589 with a total land area of $28,454 \mathrm{~km}^{2}$. Oyo state is bounded in the North by Kwara state, in the East by Osun state, in the South by Ogun and in the West by partly Ogun and partly Republic of Benin. Oyo state consists of thirty three Local Government Areas and has average daily temperature ranging between $25^{\circ} \mathrm{C}$ and $35^{\circ} \mathrm{C}$ almost throughout the year. The climate in the state favours cultivation of crops like maize, yam, cassava, millet, cocoa, rice etc.

\subsection{Data Collection and Sampling Technique}

The data, mainly from primary sources, were collected from 120 organic and inorganic fertilizers users selected using multistage sampling techniques from three Local Government Areas. The three Local Government Areas were purposively selected at the first stage. The second stage involved a simple random selection of 40 farmers from each of the three LGAs, making 120 respondents. Data were collected with the aid of well-structured questionnaire.

\subsection{Data Analysis}

Descriptive statistical analysis was used to to describe the respondents' socio-economic characteristic, benefits of fertilizer use and constraint to assessing fertilizer in the study area. Multinomial Logit Analysis and Budgetary Technique Analysis were used to determine the factors affecting the choice of fertilizer and estimating the cost and return of fertilizer users.

\subsubsection{Budgetary Technique}

This was used to estimate the cost and returns of maize farmers in the study area.

$$
\begin{aligned}
& \mathrm{GM}=\mathrm{TR}-\mathrm{TVC} \\
& \mathrm{NR}=\mathrm{TR}-\mathrm{TC} \\
& \mathrm{TC}=\mathrm{TVC}+\mathrm{TFC}
\end{aligned}
$$

Where:

$\mathrm{GM}=$ Gross margin

$\mathrm{TR}=$ Total Revenue

$\mathrm{TVC}=$ Total Variable cost

$\mathrm{TFC}=$ Total Fixed Cost

$\mathrm{NR}=$ Net Returns

$\mathrm{TC}=$ Total Cost.

\subsubsection{Multinomial Logit Analysis}

The multinomial logit model was used to assess the farmers' preference for various fertilizers options in the study area. The model was chosen based on survey results that revealed the farmers' preference (dependent variable) which was a categorical variable which can take three (3) categories or levels. These categories were assigned numbers 0,1 and 2 . 0 was used to indicate the combined (organic and inorganic) fertilizer users group; 1 for the only organic fertilizer users group and 2 was used to indicate the inorganic fertilizer users group. The organic and inorganic fertilizer users group was taken as the reference group. The multinomial logit model will therefore be used to identify the variables that make farmers belong to categories 0 (organic and inorganic fertilizer users group) and 1 (organic fertilizer users group) 2 (the inorganic fertilizer users group) as follows. The probability that the $i t h$ household belongs to the $j$ th fertilizer user group $P i j$ reduces to:

$$
P i j=\frac{e^{\beta j X i}}{\Sigma \mathbf{e}^{\beta j X \mathbf{X}}} \mathrm{k}=\mathrm{j}
$$

According to [14], the model makes the choice of probabilities on individual characteristics of agents.

Following [15], the basic model is written as:

$$
\mathrm{Pij}=\frac{\mathrm{e}^{\beta \mathrm{jXi}}}{\Sigma \mathbf{e}^{\beta \mathrm{jXi}}} \mathrm{k}=0
$$

Where $i=1,2,----n$ variables; $k=0,1,---j$ groups and $\mathrm{b}$ $j$ is vector of parameters that relates $X j_{-} s$ to the probability of being in group $\mathrm{j}$ where there are $j+I$ groups. 
Where

$\mathrm{X}_{1}=$ Gender $($ Male $=1$, Female $=0)$

$\mathrm{X}_{2}=$ Age (years)

$\mathrm{X}_{3}=$ Educational level (years)

$\mathrm{X}_{4}=$ Farm size (hectares)

$\mathrm{X}_{5}=$ Marital Status $($ single $=1$, married $=2$, widowed/divorced $=3$ )

$\mathrm{X}_{6}=$ Farming experience (years)

$\mathrm{X}_{7}=$ Household size (numbers)

$\mathrm{X}_{8}=$ Membership of cooperative (yes $=1$, otherwise $=0$ )

$\mathrm{X}_{9}=$ Access to extension service $(\mathrm{yes}=1$, otherwise $=0$ )

$\mathrm{X}_{10}=$ Access to loan $(\mathrm{yes}=1$, otherwise $=0$ )

$\mathrm{X}_{11}=$ Primary Occupation (farming $=1$, non-farming activities $=0$ )

\section{Results and Discussions}

\subsection{Socio-economic Characteristics of Maize Farmers}

The analysis of the socio-economic characteristics of the respondents is presented in Table 1 . The study revealed that the respondents were mostly male (77 percent) with majority of them married (67 percent) and relatively old people with about 79 percent having ages more than or equal to 50 years but with large household size. This finding may have implication on farming activities. It was also revealed that the major occupation of the respondents was mainly farming (80 percent) and they were well experienced but with relatively low education since about 40.0 percent had secondary education and above. Only 93 percent of the respondents belonged to cooperative societies and with about 59 percent having no access to loan. Only 74 percent had access to extension services. All this putting aside the use of fertilizer either organic or inorganic might have effect on the yield of maize farmers in the study area.

Table 1. Analysis of major findings on socio-economic characteristics of the respondents.

\begin{tabular}{lll}
\hline Variables & Frequency & Percentage \\
\hline Gender (male) & 92 & 76.67 \\
Marital Status (married) & 80 & 66.67 \\
Age ( $\geq$ 50years) & 95 & 79.17 \\
Primary Occupation (farming) & 96 & 80.00 \\
Household size ( $>5$ members) & 116 & 96.67 \\
Farming experience ( $>15$ years) & 100 & 83.33 \\
Educational level ( $\geq$ secondary education) & 48 & 40.00 \\
Extension services (No visit) & 89 & 74.17 \\
Membership of cooperative society & 112 & 93.33 \\
Access to loan & 49 & 40.83 \\
Farm size ( $\geq 4$ hectares) & 65 & 54.17 \\
Mode of land acquisition (inheritance) & 99 & 82.50 \\
Labour type (family labour) & 69 & 57.50 \\
Source of finance (Personal savings) & 94 & 78.33 \\
\hline
\end{tabular}

Source: Field survey, 2015

\subsection{Determinants of Choice for Organic and Inorganic Fertilizers}

The result of determinants of choice for organic and inorganic fertilizers by farmers in Oyo State is presented in Table 2. The likelihood ratio test for the model lambda $(\lambda)$ is 265.67 which is significant at 5 percent. The multinomial logistic estimate for the organic fertilizers users indicates that educational level and farming experience were statistically significant at $1 \%$ each while access to loan, primary occupation, and farm size were statistically significant at 5\% each.

Table 2. Determinants of choice of fertilizer among the farming households.

\begin{tabular}{|c|c|c|}
\hline Variables & Users of Organic Fertilizers Parameters & Users of Inorganic Fertilizers Parameters \\
\hline Age & $-0.586(0.564)$ & $-0.013(0.041)$ \\
\hline Educational Level & $-0.802(0.203) * * *$ & $0.038(0.009) * * *$ \\
\hline Household Size & $0.338(0.229)$ & $0.001(0.015)$ \\
\hline Access to loan & $-1.477(0.325) * *$ & $0.008(0.015)$ \\
\hline Access to Extension Contact & $-0.044(0.027)$ & $-0.353(0.097)$ \\
\hline Primary Occupation & $-0.916(0.215) * *$ & $0.216(0.034) * *$ \\
\hline Farming Experience & $-0.044(0.047)^{* * *}$ & $0.009(0.012)^{* * *}$ \\
\hline Membership of Cooperative & $0.249(0.207)$ & $0.305(0.015) * *$ \\
\hline Farm Size & $-0.046(0.204)^{* *}$ & $-0.034(0.015) * *$ \\
\hline Source of Loan & $-0.022(0.015)$ & $-0.665(0.741)$ \\
\hline Constant & $1.319(1.375)$ & $0.128(0.009)$ \\
\hline Log Likelihood Function & 14.874 & \\
\hline Likelihood ratio $(\lambda)$ & 265.67 & \\
\hline$\rho^{2}$ & 85.9 & \\
\hline $\mathrm{n}$ & 120 & \\
\hline
\end{tabular}

Note: Figures in brackets are the t-value of the estimated regression coefficients.

** represents $5 \%$ at significance level

Source: Field Survey, 2015

The use of organic fertilizer is not affected by increase in

farmers' level of education, access to loan, farming 
experience and farm size. These variables were the major determinants of organic fertilizers usage in the study area. Also, the multinomial logistic estimate for the inorganic fertilizers users among the farming households revealed that educational level and farming experience were statistically significant at $1 \%$ each while primary occupation, membership of cooperative and farm size were all significant at $5 \%$ each. Inorganic fertilizer usage is greatly influenced by the use of inorganic fertilizer as there are instructions that must be adhered to before they can be used. Farmers that are not educated may not be able to mix these chemical fertilizers in the appropriate rate and timing. Farmers with low farm sizes are able to enjoy the benefits of agricultural intensification through the use inorganic fertilizer. Higher yield can be derived from a small portion of land that can be well managed due to the use of this type of fertilizer. Cooperative membership and farming experience influenced farmers' choice for inorganic fertilizers in the study area.

\subsection{Costs and Returns of Inorganic and Organic Fertilizers Users}

The budgetary analysis (Table 3 ) showed that the TVC formed the bulk $87.64 \%$ of the TC and the TFC was just
$12.36 \%$ for inorganic fertilizer users, while the TVC of organic fertilizer users culminated about $86.52 \%$ of the TC and the TFC was just $13.47 \%$. This implies that farmers who want to be cost efficient have to reduce TVC especially the cost of labour that is more than three quarter $(65.29 \%)$ of the total cost (Inorganic fertilizer users) and 66.12 percent of the total cost of organic fertilizer users respectively. TFC is small probably because of very low cost of land rent in the area. This is typical of core rural communities in Southwestern Nigeria where most lands are currently held by inheritance as presented in the result. The total profit of $\$ 85,474.00$ (\$431.69) per hectare and percentage profit of 58.63\% which were realized by inorganic fertilizer users shows that maize farming is a highly profitable venture in the area. Organic fertilizer users earn more ( $116,590.00)(\$ 588.83)$ as the cost of organic fertilizer which is either from plant or animal sources can be reasonably justified, unlike the high cost of chemical fertilizers. The cost ratio showed that an inorganic farmer user that invested $¥ 1$ realized $\$ 1.59$ as revenue or gained $¥ 0.59 \mathrm{k}$ on each Naira expended, while an organic farmer user that invested $\$ 1$ realized $\$ 1.67$ as revenue or gained $¥ 0.67 \mathrm{k}$ on each Naira expended.

Table 3. Budgetary analysis.

\begin{tabular}{|c|c|c|}
\hline Items & Inorganic Fertilizer Users & Organic Fertilizer Users \\
\hline \multicolumn{3}{|l|}{ Variable Costs ( $($ ) } \\
\hline Cost of labour & $83580(\$ 422.12)(65.29 \%)$ & $131500(\$ 664.14)(66.12 \%)$ \\
\hline Cost of herbicides & $13685(\$ 69.12)(10.69 \%)$ & - \\
\hline Cost of fertilizer & 14937 (\$75.44) (11.69\%) & $40570(\$ 204.89)(20.20 \%)$ \\
\hline Total variable cost (TVC) & $112202(\$ 566.68)(87.64 \%)$ & 172070 (\$869) (86.52\%) \\
\hline \multicolumn{3}{|l|}{ Fixed Costs ( } \\
\hline land rent & 4567 (\$23.07) (3.57\%) & $7200(\$ 36.37)(3.62 \%)$ \\
\hline Depreciation & 11257 (\$56.85) (8.79\%) & 19600 (\$98.99) (9.85\%) \\
\hline Total fixed cost (TFC) & $15824(\$ 79.92)(12.36 \%)$ & 15824 (\$79.92) (13.47\%) \\
\hline Total cost $(\mathrm{TC}=\mathrm{TVC}+\mathrm{TFC})$ & $128026(\$ 646.59)(100 \%)$ & 198870 (\$1004) (100\%) \\
\hline \multicolumn{3}{|l|}{ Total revenue ( } \\
\hline Income (TR) & $213500(\$ 1078.29)$ & $315460(\$ 1593.23)$ \\
\hline Profit (TR - TC) & $85474(\$ 431.69)$ & $116590(\$ 588.84)$ \\
\hline
\end{tabular}

Source: Field Survey, 2015

\subsection{Benefits Derivable from Using Both Fertilizers}

From Table 4, it can be revealed that different benefits were derivable from using both organic and inorganic fertilizers. It was disclosed that $91.7 \%$ of the farmers indicated that consistent use of either organic or inorganic fertilizers brings about increase in output which subsequently leads to increase in income. Also, $62.5 \%$ of the maize farmers believed that both organic and inorganic fertilizers replenish soil. While $68.3 \%$ of the maize farmers indicated that both organic and inorganic bring about improvement in market value of maize, $72.5 \%$ of the farmers concluded that enhanced income could be achieved through the use of organic and inorganic fertilizers.
Table 4. Benefits of Using Organic and Inorganic Fertilizers.

\begin{tabular}{lll}
\hline Benefits & Frequency & Percentage \\
\hline Increase in output & 110 & 91.67 \\
It brings about enhanced income & 87 & 72.50 \\
It replenishes soil & 75 & 62.50 \\
It improves market value & 82 & 68.33 \\
\hline
\end{tabular}

Multiple Responses

Source: Field Survey, 2015

\subsection{Constraints Encountered in Accessing Both Fertilizers}

From Table 5, it can be revealed that many challenges were encountered in the course of accessing both the organic and inorganic fertilizers. It was disclosed that $79.2 \%$ of the respondents interviewed complained high cost 
of fertilizers as the major constraints facing them while $56.7 \%$ indicated lack of credit facility as their bane. Also, $47.5 \%$ of the farmers revealed that lack of subsidy is their major threat to accessing fertilizers. It was made known from the Table that $38.3 \%$ of the farmers complained about lack of storage facility while $60.8 \%$ of the interviewees indicated non availability of fertilizers. It was also revealed from the Table that $56.7 \%$ of the farmers indicated unnecessary hoarding as the constraints being faced in the locality when accessing fertilizers while $63.3 \%$ of the farmers complained about labour availability. Lastly, $37.5 \%$ of the farmers indicated government policy while $58.3 \%$ made mention of delay in supply or delivery as their constraints in accessing fertilizers.

Table 5. Constraints Encountered in Accessing both Fertilizers.

\begin{tabular}{lll}
\hline Constraints & Frequency & Percentage \\
\hline High cost of fertilizer & 95 & 79.17 \\
Lack of credit facilities & 68 & 56.67 \\
Lack of subsidy & 57 & 47.50 \\
Lack of storage facilities & 46 & 38.33 \\
Non-availability of fertilizers & 73 & 60.83 \\
Unnecessary hoarding & 68 & 56.67 \\
Labour availability & 76 & 63.33 \\
Political instability & 45 & 37.50 \\
Delay in supply / delivery & 70 & 58.33 \\
\hline
\end{tabular}

Multiple Responses

Source: Field Survey, 2015

\section{Conclusion and Recommendations}

The study concluded that the determinants of choice for organic fertilizers were educational level, access to loan, access to extension contact, primary occupation and farm size, the determinants of choice for inorganic fertilizers were found to be educational level, primary occupation, farming experience, membership of cooperative and farm size.

From the costs and returns breakdown of inorganic fertilizers users in the study area, the cost ratio showed that a farmer that invested $¥ 1$ realized $\$ 1.59$ as revenue or gained $¥ 0.59 \mathrm{k}$ on each Naira expended while a farmer (organic fertilizers users) who invested $\$ 1$ realized $\$ 1.67$ as revenue or gained $\$ 0.67 \mathrm{k}$. Farmers can gain more if they can rationalize the use of fertilizer to the organic type. Organic fertilizer use can reduce the cost of production of farmers.

It is therefore recommended that government should embark on programmes that will encourage youths' involvement in maize production in the study area. Through consistent extension service delivery, maize farmers should be educated and encouraged to adopt the use of inorganic fertilizers because it is cost efficient. Government and individual concerned should discourage unnecessary hoarding of fertilizers in order to ensure its regular availability; and supplying of fertilizers by government at subsidized rate to farmers in the study area should be encouraged.

\section{References}

[1] International Institute of Tropical Agriculture (2009). Maize, http://www.iita.org/maize PMB 5320, Ibadan, Oyo State, Nigeria.

[2] Liverpool-Tasie, L. S. O., Omonona, B. T., Sanou, A., \& Ogunleye, W. (2015). Is increasing inorganic fertilizer use in Sub-Saharan Africa a profitable proposition? Evidence from Nigeria. World Bank Policy Research Working Paper, (7201).

[3] Smaling, E. M. A. (1993). Soil nutrient depletion in SubSaharan Africa. In The Role of Plant Nutrients for Sustainable Food Crop Production in Sub-Saharan Africa, 47-61 (Eds H. Van Reuler and W. Prins). Leidschendam, Netherlands: VKP.

[4] Kherallah, M., C. Delgado, E. Gabre-Madhin, N. Minot, and M. Johnson (2002). Reforming Agricultural Markets in Africa, Volume 50. Baltimore, Maryland: The Johns Hopkins University Press.

[5] Liverpool-Tasie, L. S. O., Omonona, B. T., Sanou, A., \& Ogunleye, W. (2016). A profitability analysis of fertilizer use for maize production in Nigeria. GISAIA: Policy Paper February 2016.

[6] Mwangi, J. N., Mugendi, D. N. and O’Neill, K. M. (1998). Crop yield response to incorporation of leaf prunnings in sole and alley cropping systems. East Africa Agricultural Journal 62:209-218.

[7] Mugwe, J., Mugendi, D., Mucheru-Muna, M., Merckx, R., Chianu, J. and Vanlauwe, B. (2009). Determinants of the decesion to adopt integrated soil fertility management practices by smallholder farmers in the Central highlands of Kenya. Experimental Agriculture 45:61-75.

[8] Vanlauwe, B., Bationo, A., Chianu, J., Giller, K. E., Merckx, R., Mokwunye, U., Ohiokpehai, O., Pypers, P., Tabo, R., Shepherd, K. D., Smaling, E. M. A., Woomer, P. L. and Sanginga, N. (2010a). Integrated soil fertility management. Operational definition and consequences for implementation and dissemination. Outlook on Agriculture 39:17-24.

[9] Bationo, A. and Waswa, B. S. (2011). New challenges and opportunities for integrated soil fertility management in Africa. In Innovation as Key to the Green Revolution in Africa. Exploring the Scientific Facts, Vol 1 (Eds A. Bationo, B. Waswa, J. M. Okeyo, F. Maina and J. Kihara). New York, NY: Springer.

[10] Murwira, H. K.,Mutuo, P. K., Nhamo,N., Marandu, A. E.,Rabeson,R., Mwale, M. and Palm, C. A. (2002). Fertilizer equivalency values of organic materials of different quality. In Integrated Plant Nutrients Management in Sub-Saharan Africa: From Concept to Practice, 113-152 (Eds B. Vanlauwe, J. Diels, N. Sanginga and R. Merckx). Wallingford, $\mathrm{UK}$ : CAB International.

[11] Sanginga, N. and Woomer, P. L. (Eds) (2009). Integrated Soil Fertility Management in Africa: Principles, Practices and Development Process. Nairobi, Kenya: Tropical Soil Biology and Fertility Institute of the Centre for Tropical Agriculture, $263 \mathrm{pp}$.

[12] Kimani, S. K., Macharia, J. M., Gachengo, C., Palm, C. A. and Delve, R. J. (2004). Maize production in the central highlands of Kenya using cattle manures combined with modest amounts of mineral fertilizer. Uganda Journal of Agricultural Sciences 9:480-490. 
[13] Tittonell, P., Corbeels, M. and van Wijk, M. T. (2008). Combining organic and mineral fertilizers for integrated soil fertility management in smallholder farming systems of Kenya: explorations using the crop-soil model FIELD. Agronomy Journal 100:1511-1526.

[14] Maddala, G. S. (1983), Limited-Dependent and Qualitative Variables in Economics, New York: Cambridge University Press, pp. 257-91.
[15] Maddala, G. S., 1990, Estimation of dynamic disequilibrium models with rational expectations: The case of the commodity markets, in: L. A. Winters and D. Sapsford, eds., Primary commodity prices: Economic models and policy (Cambridge University Press, Cambridge). 